\title{
PENGARUH CURRENT RATIO, DEBT TO EQUITY RATIO, RETURN ON ASSET, RETURN ON EQUITY TERHADAP HARGA SAHAM PADA INDEKS LQ 45 DI BEI PERIODE 2010-2014
}

\author{
Oleh \\ Adriana Kundiman \\ Alumni STIE Totalwin Semarang \\ Lukmanul Hakim \\ Dosen STIE Totalwin Semarang
}

\begin{abstract}
Abstrak
Penelitian ini bertujuan untuk mengetahui pengaruh current ratio,debt to equity ratio, return on asset dan return on equity terhadap harga saham pada perusahaan LQ45 yang terdaftar di Bursa Efek Indonesia tahun 2010-2014. Penelitian ini dibuat karena masih ada terdapat perbedaan hasil penelitian antara penelitian satu dengan penelitian lainnya, dan agar dapat di pergunakan untuk memprediksi fluktuasi harga saham. Penelitian ini menggunakan alat analisis statistik regresi linear berganda untuk menguji hipotesisnya. Variabel yang di gunakan dalam penelitian ini adalah current ratio, debt to equity ratio, return on asset dan return on equity terhadap harga saham. Jenis data yang digunakan dalam penelitian ini adalah data sekunder yang berupa catatan serta laporan yang diambil dari Indonesian Capital Market Directory (ICMD).
\end{abstract}

Kata Kunci : Current ratio, Debt to equity ratio, Return on asset, Return on Equity dan Harga Saham.

\section{PENDAHULUAN}

Suatu perusahaan tentunya selalu memiliki tujuan didalamnya. Tujuan-tujuan yang ingin dicapai oleh suatu perusahaan tentunya tidak hanya satu saja, melainkan banyak hal, tetapi ada satu tujuan yang ditekankan perusahaan. Salah satu contoh tujuan yang biasanya diinginkan oleh perusahaan adalah memaksimalkan tingkat pengembalian. Tujuan perusahaan yang seperti ini juga yang biasanya diinginkan para investor untuk berinvestasi pada suatu perusahaan. Dalam hal ini pasar modal tentunya memiliki pengaruh yang cukup besar terhadap perusahaan, sebab pasar modal merupakan sarana untuk memperoleh dana yang bersumber dari masyarakat ke berbagai sektor yang melaksanakan investasi.

Horigan ( dalam Sari, 2012) menyatakan bahwa rasio keuangan berguna untuk memprediksi kesulitan keuangan perusahaan, hasil operasi, kondisi perusahaan saat ini dan pada masa mendatang, serta sebagai pedoman bagi investor mengenai kinerja masa lalu dan masa yang akan mendatang. 
Harga saham adalah harga suatu saham pada pasar yang sedang berlangsung di bursa efek.Pemegang saham akan menerima pengembalian atas modalnya berupa dividen dan Capital gain. (Sunariyah, 2006). Tingginya harga saham akan mengurangi kemampuan para investor untuk membeli harga saham tersebut. Hukum permintaan dan penawaran kembali berlaku dan sebagai konsekuensinya harga saham yang tinggi tersebut akan menurun sampai tercipta posisi keseimbangan yang baru (Ewijaya,1999).

Indeks LQ45 sebagai salah satu indikator indeks saham di BEI dapat dijadikan acuan sebagai bahan untuk menilai kinerja perdagangan saham. Indeks ini hanya terdiri dari 45 saham yang telah terpilih setelah melalui beberapa kriteria pemilihan sehingga akan terdiri dari saham - saham dengan likuiditas tinggi (Rinati, 2008). Oleh karena itu perlu mengkaji pengaruh CR, DER, ROA dan ROE terhadap harga saham di perusahaan yang tercantum dalam indeks LQ 45 yang terdaftar di BEI.

Tujuan perusahaan untuk memaksimalkan nilai perusahaan dapat dicapai dengan melaksanakan fungsi-fungsi manajemen. Salah satu keputusan yang harus diambil untuk memaksimalkan nilai perusahaan adalah keputusan pendanaan, dimana perusahaan akan menentukan struktur modal yang terbaik untuk mencapai tujuan perusahaan. Besarnya pengunaan dana eksternal maupun internal akan mempengaruhi nilai perusahaan. Hal ini sesuai dengan hasil penelitian yang menunjukan bahwa DER berpengaruh signifikan terhadap harga saham perusahaan. Hal ini berarti bahwa kenaikan nilai DER dapat meningkatkan harga saham perusahaan secara signifikan. Penelitian ini bertolak belakang dengan penelitian Dwiatma Patriawan (2009) yang meneliti 24 perusahaan Wholesale and Retail Trade yang terdaftar di BEI. Hasil penelitian ini menunjukan $D E R$ tidak berpengaruh terhadap harga saham.

Pada saat permintaan saham meningkat, maka harga saham tersebut akan cenderung meningkatkan. Sebaliknya, pada saat banyak orang menjual saham, maka harga saham tersebut cenderung akan mengalami penurunan (Pakarti dan Anoraga, 2001 ). Secara teori apabila tingkat rasio keuangan tertentu mengalami kenaikan maka dapat diambil kesimpulan bahwa kinerja perusahaan tersebut optimal. Sehingga apabila kinerja perusahaan tersebut dinilai positif, seharusnya investor berani menginvestasikan dananya untuk perusahaan tersebut, dan jika banyak investor 
cenderung ingin membeli saham perusahaan tersebut maka harga saham perusahaan tersebut akan mengalami tren yang meningkat.

Investasi dilakukan dengan tujuan untuk memperoleh keuntungan sesuai dengan yang di harapkan. Oleh karena itu, sebelum melakukan keputusan investasi, investor perlu melihat dan menganalisa laporan keuangan perusahaan yang bersangkutan. Pada prinsipnya, semakin baik perusahaan dalam menghasilkan keuntungan, maka akan meningkatkan pula harga saham. Penelitian ini bertujuan untuk mengetahui pengaruh rasio keuangan yang di wakili oleh Current Ratio (CR), Debt to Equity Ratio (DER), Return On Asset (ROA), dan Return On Equity (ROE) dan terhadap harga saham, yang menjadi perbedaan penelitian ini dengan penelitian sebelumnya adalah pada objek penelitian, periode penelitian dan rasio keuangan yang digunakan. Objek dalam penelitian ini adalah perusahaan indeks LQ45yang terdaftar di BEI dengan periode penelitian selama 4 tahun (2010-2014), dan rasio keuangan yang digunakan terdiri dari : current rati $(C R)$, debt to equity ratio (DER), return on asset (ROA), dan return on equity $(R O E)$.

\section{PAPARAN TEORITIS}

\section{Teori Asimetri Informasi}

Konsep Signaling dan asimetri informasi berkaitan erat. Teori asimetri mengatakan bahwa pihak-pihak yang berkaitan dengan perusahaan tidak mempunyai informasi yang sama mengenai prospek dan resiko perusahaan. Pihak tertentu mempunyai informasi yang lebih baik dibandingkan pihak lainnya.Manajer biasanya mempunyai informasi yang lebih baik dari pihak luar (misalkan investor).Karena itu bisa dikatakan terjadi asimetri informasi antara manajer dengan investor. Investor yang merasa mempunyai informasi yang lebih sedikit akan berusaha menginterprestasikan perilaku manajer. Dengan kata lain perilaku manajer termasuk dalam hal menentukan struktur modal, bisa dianggap sebagai signal oleh pihak luar (Investor). Menurut Myer dan Majluf (1977), ada asimetri informasi antara manajer dengan pihak luar.Manajer mempunyai informasi yang lebih lengkap mengenai kondisi perusahaan dibandingkan dengan pihak luar. Pada saat lembaga perantara yang bertugas mengefektifkan aliran dana dari pihak surplus dana ke pihak defisit dana. 


\section{Teori Signaling}

Ross (1977) mengembangkan model dimana struktur modal (penggunaan utang) merupakan signal yang disampaikan oleh manajer ke pasar. Jika manajer mempunyai kenyakinan bahwa prospek perusahaan baik, dan karenanya ingin agar harga saham meningkat, akan dikomunikasikan hal tersebut ke Investor. Salah satu cara yang paling sederhana adalah mengatakannya secara langsung "perusahaan kami mempunyai prospek yang baik". Manajer bisa menggunakan utang sebagai signal yang lebih dipercaya (credible). Jika utang meningkat maka kemungkinan bangkrut akan semakin meningkat. Jika perusahaan mengalami kebangkrutan maka manajer akan "terhukum" seperti reputasi hancur dan tidak dipercaya menjadi manajer. Karena itu perusahaan yang meningkatkan utang bisa dipandang sebagai perusahaan yang yakin dengan prospek perusahaan di masa mendatang.Karena cukup yakin, maka manajer perusahaan tersebut berani menggunakan utang yang lebih besar. Investor diharapkan akan menangkap signal tersebut, signal bahwa perusahaan mempunyai prospek yang baik. Dengan demikian utang merupakan tanda atau signal positif.Suatu pasar modal dikatakan likuid jika penjual dapat menjual dan pembeli dapat membeli surat-surat berharga dengan cepat.Pasar modal dikatakan efisien jika dari surat-surat berharga mencerminkan nilai dari perusahaan secara akurat. Jika pasar modal efisien, harga dari surat berharga juga mencerminkan penilaian dari investor terhadap prospek laba dimasa mendatang serta kualitas dari manajemennya (Eduardus Tandelin, 2001).

\section{Harga Saham}

Saham adalah surat berharga yang dikeluarkan oleh sebuah perusahaan yang berbentuk perseroan terbatas atau yang biasa disebut emiten (Sjahrial, 2009). Menurut Suhartono dan Qudsi (2009), saham adalah tanda penyertaan atau pemilikan seseorang atau badan usaha dalam suatu perusahaan atau perseroan terbatas.Dengan menyertakan modal tersebut, maka pihak tersebut memiliki klaim atas pendapatan perusahaan, klaim atas asset perusahaan, dan berhak hadir dalam Rapat Umum Pemegang Saham (RUPS). Pada sisi yang lain, saham merupakan instrument investasi yang banyak dipilih para investor karena saham mampu memberikan tingkat keuntungan yang menarik (Martalena dan Maya, 2011). Besar kecilnya keuntungan yang dibagikan tergantung pada jumlah saham yang dimiliki dalam perusahaan. Harga saham adalah nilai saham yang ditentukan oleh kekuatan penawaran jual beli saham 
pada mekanisme pasar tertentu dan merupakan harga jual dari investor yang satu ke investor lainnya (Darmadji dan Fakhruddin ,2006). Nilai perusahaan dapat digambarkan dengan adanya perkembangan harga saham perusahaan di pasar modal.Semakin tinggi harga saham suatu perusahaan, maka semakin tinggi pula nilai perusahaan tersebut.

Menurut Suad Husnan dan Enny Pudjiastuti (2004) saham atau sekuritas merupakan secarik kertas yang menunjukkan hak pemilik kertas tersebut untuk memperoleh bagian dari prospek atau kekayaan perusahaan yang menerbitkan sekuritas tersebut dan berbagai kondisi untuk melaksanakan hak tersebut.

\section{Rasio Likuiditas (Liquidity Ratio)}

Rasio lancar (Current ratio) adalah ukuran yang umum yang digunakan atas solvensi jangka pendek, kemampuan suatu perusahaan dalam memenuhi kebutuhan utang ketika ketika jatuh tempo. (Weston, 2008). Rasio yang menunjukkan kemampuan perusahaan dalam memenuhi atau membayar kewajiban atau utang lancar (utang jangka pendek) dengan aktiva lancar tanpa memperhitungkan nilai sediaan (Kasmir,2010).

Semakin tinggi rasio ini, semakin besar kemampuan perusahaan untuk membayar kewajiban jangka pendek.Artinya, setiap saat perusahaan memiliki kemampuan untuk melunasi kewajiban-kewajiban jangka pendeknya.Tetapi rasio lancar yang terlalu tinggi juga menunjukkan manajemen yang buruk atas sumber likuiditas.Kelebihan dalam aktiva lancar seharusnya digunakan untuk membayar dividen, membayar hutang jangka panjang atau untuk investasi yang bisa menghasilkan tingkat kembalian lebih (Darsono dan Ashari, 2005).

\section{Rasio Solvabilitas}

Rasio utang merupakan rasio yang digunakan untuk mengukur perbandingan antara total utang dan total aktiva. Dengan kata lain, rasio utang mengukur seberapa besar aktiva perusahaan dibiayai oleh utang. Kasmir (2010) mendefinisikan debt to equity ratio sebagai "ukuran yang dipakai untuk menganalisis laporan keuangan untuk memperlihatkan besarnya jaminan yang tersedia untuk kreditor.

Rasio ini berguna untuk mengetahui jumlah dana yang disediakan kreditor dengan pemilik perusahaan, dan setiap rupiah modal sendiri yang dijadikan untuk jaminan utang. Semakin tinggi rasio, semakin rendah pendanaan perusahaan yang 
disediakan oleh pemegang saham. Dari perspektif kemampuan membayar jangka panjang, semakin rendah rasio akan semakin baik kemampuan perusahaan dalam membayar kewajiban jangka panjang (Darsono dan Ashari, 2005).

\section{Rasio Profitabilitas}

Return On Asset (ROA) atau pengembalian Asset, bahwa dibeberapa referensi lainnya rasio ini juga ditulis dengan Rasio Return On Investment (ROI) Rasio ini melihat sejauh mana investasi yang telah ditanamkan mampu memberikan pengembalian keuntungan sesuai dengan yang diharapkandan investasi tersebut sebenarnya sama dengan asset perusahaan yang ditanamkan atau ditempatkan. (Munawir, 2010). Rasio return on equity (ROE) atau laba atas equity. Rasio ini mengkaji sejauh mana suatu perusahaan mempergunakkan sumber daya yang dimiliki untuk mampu memberikan laba atas equitas. (Kasmir, 2010).

Dengan mengetahui rasio ini, kita dapat menilai apakah perusahaan efisien dalam memanfaatkan aktivanya dalam kegiatan operasional perusahaan.Karena semakin besar rasio ini, maka semakin baik kemajuan perusahaan untuk mendapatkan laba yang tinggi.Dan sebaliknya, apabila nilai rasio semakin rendah, maka perusahaan dianggap kurang efisien dalam memanfaatkan aktiva dalam operasionalnya.(Syamsuddin, 2009).

Rasio ini tidak menggambarkan besarnya persentase keuntungan bersih yang diperoleh perusahaan untuk setiap penjualan karena adanya unsur pendapatan dan biaya operasional. Semakin besar rasio ini, maka dianggap semakin baik kemampuan perusahaan untuk mendapatkan laba yang tinggi (Darsono dan Ashari, 2005).

\section{Kerangka Pemikiran Teoritis}

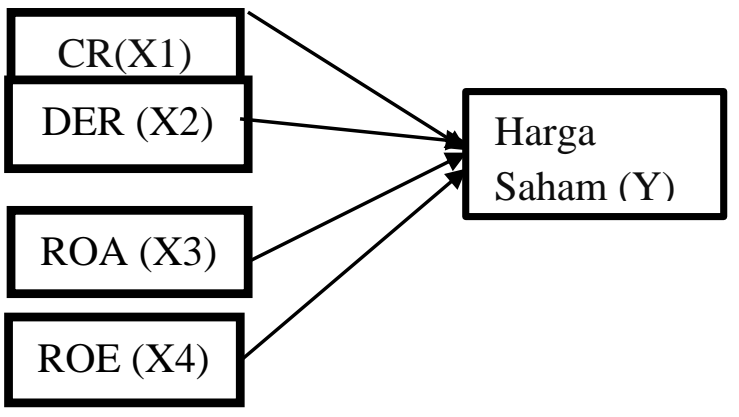

H1: Current Ratio diduga berpengaruh secara signifikan terhadap Harga Saham. 
H2: Debt To Equity Ratio (DER) diduga berpengaruh secara signifikan terhadap Harga Saham.

H3: Return On Asset diduga berpengaruh secara signifikan terhadap Harga Saham.

H4: Return On Equity diduga berpengaruh secara signifikan terhadap Harga Saham.

H5: Current Ratio, Debt To Equity Ratio, Return On Asset, Return On Equity diduga berpengaruh secara signifikan terhadap Harga Saham.

\section{METODE PENELITIAN}

\section{Populasi Dan Sampel}

Menurut Ferdinand (2006 dalam Pratiwi, 2012), Populasi adalah gabungan dari seluruh elemen yang berbentuk peristiwa, hal, atau orang yang memiliki karakteristik serupa yang menjadi pusat perhatian peneliti, karena itu dipandang sebagai sebuah semesta penelitian.Adapun Populasi dalam penelitian ini adalah semua perusahaan yang bergerak pada Perusahaan Manufaktur yang terdaftar di Bursa Efek Indonesia (BEI).

Populasi dalam penelitian ini adalah seluruh perusahaan yang terdaftar dalam golongan LQ 45 pada Bursa Efek Indonesia.

Sampel adalah sub kelompok atau sebagian dari populasi (Sekaran, 2006). pengambilan sampel menggunakan teknik Non Probability Sampling dengan metode Purposive Sampling (pengambilan disengaja berdasarkan kriteria tertentu). Kriteria dalam hal ini yaitu:

1. Perusahaan yang mampu konsisten berada dalam golongan LQ 45 selama 5 tahun terakhir

2. Perusahaan yang terdaftar sebagai perusahaan LQ45 dalam empat tahun secara berturut-turut

3. Jumlah Aset dinilai sedang yaitu berada di kisaran $10-100$ Triliun pada tahun terakhir.

4. Perusahaan yang memiliki data yang lengkap selama periode penelitian untuk factor-faktor yang teliti, yaitu Current Ratio, Debt To Equity Ratio, Return On Asset, dan Return On Equity. 


\section{ANALISIS DATA}

\section{Uji Asumsi Klasik}

\section{Pengujian Normalitas}

Uji normalitas bertujuan untuk menguji apakah dalam model regresi data residual mempunyai distribusi normal atau tidak.Model regresi yang baik adalah mempunyai distribusi data normal atau mendekati normal. Uji ini dilakukan dengan cara melihat penyebaran data (titik) pada sumbu diagonal atau grafik. Jika garis menyebar di sekitar garis diagonal dan mengikuti garis tersebut maka model regresi memenuhi asumsi normalitas.Apabilah data menyebar jauh dari garis diagonal dan atau tidak mengikuti arah garis diagonal, maka model regresi tidak memenuhi asumsi normalitas. Uji normalitas adalah dengan cara digunakan untuk mendeteksi apakah residual terdistribusi normal atau tidak adalah dengan analisis grafik histogram dan grafik normal probability plot secara statistic dengan onesample Kolmogorov-sminov test (1 sample- $K-S)$.

\section{One-Sample Kolmogorov-Smirnov Test}

\begin{tabular}{|ll|r|}
\hline & & $\begin{array}{r}\text { Unstandardiz } \\
\text { ed Residual }\end{array}$ \\
\hline $\mathrm{N}$ & Mean & 39 \\
Normal Parameters & a,b & .0000000 \\
& Std. & 549.7227772 \\
& Deviation & 1 \\
Most Extreme & Absolute & .162 \\
Differences & Positive & .162 \\
Kolmogorov-Smirnov Z & Negative & -.092 \\
Asymp. Sig. (2-tailed) & & 1.013 \\
\hline
\end{tabular}

a. Test distribution is Normal.

b. Calculated from data.

Berdasarkan tabel 4.3 hasil pengujian normalitas residual menunjukan sudah berdistribusi normal, yang ditunjukan nilai siknifikansi pengujian Kolmogorovsmirnov tersebut lebih besar dari 0,05 . Hal ini berarti data residual terdistribusi normal. 


\section{Uji Multikolinearitas}

Coefficients $^{\mathbf{a}}$

\begin{tabular}{|c|c|c|c|c|c|c|c|c|}
\hline \multirow[t]{2}{*}{ Model } & & \multicolumn{2}{|c|}{$\begin{array}{c}\text { Unstandardized } \\
\text { Coefficients }\end{array}$} & \multirow{2}{*}{$\begin{array}{c}\text { Standardized } \\
\text { Coefficients }\end{array}$} & \multirow[t]{2}{*}{$\mathrm{t}$} & \multirow[t]{2}{*}{ Sig. } & \multicolumn{2}{|c|}{$\begin{array}{l}\text { Collinearity } \\
\text { Statistics }\end{array}$} \\
\hline & & B & $\begin{array}{l}\text { Std. } \\
\text { Error }\end{array}$ & & & & Tolerance & VIF \\
\hline \multirow{5}{*}{1} & (Constant) & 1010.639 & 378.104 & & 2.673 & .011 & & \\
\hline & CR & 50.127 & 80.958 & .097 & .619 & .540 & .766 & 1.306 \\
\hline & DER & 145.355 & 171.739 & .230 & .846 & .403 & .253 & 3.951 \\
\hline & ROA & 173.568 & 67.665 & 1.055 & 2.565 & .015 & .110 & 9.068 \\
\hline & ROE & -101.056 & 38.399 & -1.038 & -2.632 & .013 & .120 & 8.342 \\
\hline
\end{tabular}

a. Dependent Variable: HARGA SAHAM

Berdasarkan hasil pada tabel 4.4 dapat dijelaskan bahwa nilai tolerance current ratio 0,766 debt to equity ratio 0,253 return on asset 0,110 return on equity 0,120 yang mana nilai tolerance tersebut diatas 0,10 . Hal ini berarti tidak ada korelasi antar variabel independen. Hasil perhitungan variance inflation factor (VIF) current ratio 1,306 , debt to equity ratio 3,951, return on asset 9,068, return on equity 8,342 juga menunjukan hal yang sama, dengan variable independen yang memiliki VIF di bawah dari 10. Jadi dapat di simpulkan bahwa menurut pengujian pertama, dikatakan tidak terjadi multikolinearitas antar variabel. Pengujian multikolinearitas dapat dilihat dari tabel 4.4 berikut ini:

\section{Uji Heteroskedastisitas}

Uji Heteroskedastisitas dalam penelitian ini dengan melihat grafik plot antara nilai predeksi variabel terikat (dependen ) yaitu ZPRED dengan residual SRESID. Salah satu cara untuk mendeteksi ada tidaknya heteroskedastisitas dilakukan dengan melihat ada tidaknya pola tertentu pada grafik scatterplot antara SRESID dan ZPRED dimana sumbu Y adalah Y yang telah diprediksi, dan sumbu X adalah residual ( Y prediksi- Y sesungguhnya) yang telah di-studentized (Imam Ghozali, 2001).

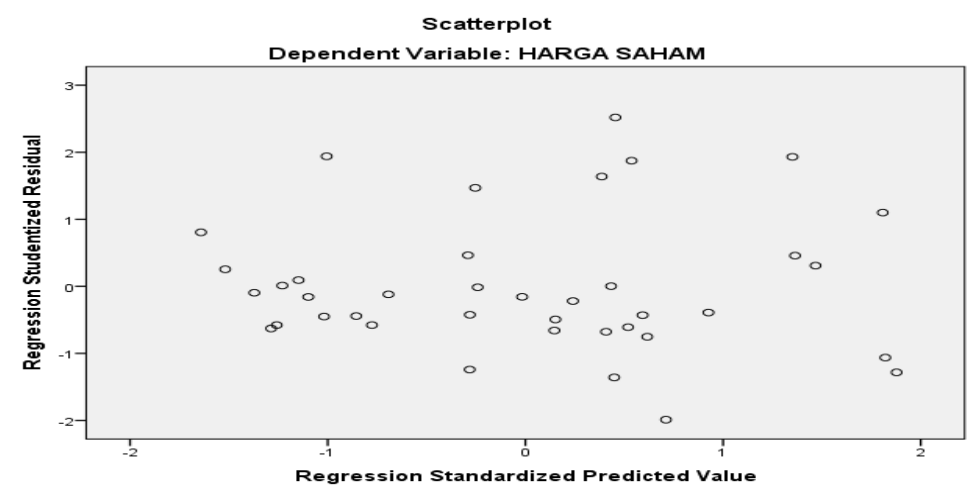


Dari tabel diatas dilihat dan diperolah bahwa scatterplot membentuk titik-titik yang secara acak serta tersebar baik diatas maupun dibawah angka 0 pada sumbuh Y. Hal ini dapat disimpulkan bahwa tidak terjadi heteroskedastisitas pada model regresi, sehingga model regresi layak dipakai untuk memprediksi harga saham berdasarkan variabel independen curren ratio, debt to equity ratio, return on asset, dan return on equity.

\section{Uji Autolorelasi}

Uji autokorelasi bertujuan untuk mengetahui apaka terjadi korelasi antara anggota serangkaian data penelitian yang di urutkan menurut waktu (time series).Untuk mendeteksi terjadinya autokorelasi dalam penelitian ini digunakan uji durbin-watson dengan melihat korelasinya.Uji durbin-watson dihitung berdasarkan jumlah selisih kuadrat nilai taksiran factor gangguan yang berurutan. Dari hasil SPSS uji autokorelasi dapat dilihat pada tabel berikut ini :

Model Summaryb

\begin{tabular}{|l|r|r|r|r|r|}
\hline Model & R & R Square & Adjusted R Square & $\begin{array}{c}\text { Std. Error of the } \\
\text { Estimate }\end{array}$ & Durbin-Watson \\
\hline 1 & $.605^{\mathrm{a}}$ & .366 & .291 & 581.16048 & 1.371 \\
\hline
\end{tabular}

a. Predictors: (Constant), ROE, DER, CR, ROA

b. Dependent Variable: HARGA SAHAM

Berdasarkan hasil uji autokorelasi diatas diperoleh nilai durbin-watson adalah sebesar 1,371 yang berada diantara 1,08 sampai dengan 1,66 sehingga dapat dikatakan tampa kesimpulan bahwa nilai tersebut tidak ada masalah autokorelasi.

\begin{tabular}{|l|l|}
\hline \multicolumn{1}{|c|}{ Durbin-Watson } & \multicolumn{1}{c|}{ Kesimpulan } \\
\hline & \\
Kurang dari 8,1 & Ada autokorelasi \\
$1,08-1,66$ & Tanpa kesimpulan \\
$1,66-2,34$ & Tidak ada autokorelasi \\
$2,34-2,92$ & Tanpa kesimpulan \\
Lebih dari 2,92 & Ada autokorelasi \\
\hline
\end{tabular}

\section{Analisis Regresi Linear Berganda}

Analisis regresi dilakukan untuk mengetahui bagaimana variabel dependen dapat diprediksi melalui variabel independen. Analisis regresi yang digunakan dalam penelitian ini adalah analisis regresi linier berganda untuk meramalkan bagaimana 
keadaan (naik atau turunnya) variabel dependen, bila dua atau lebih variabel independen sebagai faktor prediktor manipulasi (sugiyono, 2008). Dari hasil SPSS analisis regresi linier berganda dapat dilihat pada gambar dibawah ini :

ANOVA $^{a}$

\begin{tabular}{|rl|r|r|r|r|r|}
\hline Model & & Sum of Squares & \multicolumn{1}{|c|}{ df } & Mean Square & F & Sig. \\
\hline \multirow{2}{*}{1} & Regression & 6629978.582 & 4 & 1657494.646 & 4.907 & $.003^{\mathrm{b}}$ \\
& Residual & 11483415.008 & 34 & 337747.500 & & \\
& Total & 18113393.590 & 38 & & & \\
\hline
\end{tabular}

a. Dependent Variable: HARGA SAHAM

b. Predictors: (Constant), ROE, DER, CR, ROA

Berdasarkan tabel 4.8 dapat dilihat bahwa dari keempat variabel independen yang telah dimasukan ke dalam model regresi.Variabel current ratio tidak berpengaruh signifikan terhadap harga saham. Hal tersebut dapat dilihat dari probabilitas signifikansi sebesar 0,540 diatas 0,05 . Variabel debt to equity ratio tidak berpengaruh signifikan terhadap harga saham. Hal tersebut dapat dilihat dari profitabilitas signifikansi sebesar 0,403 diatas 0,05. Variabel return on asset berpengaruh positif signifikan terhadap harga saham. Hal tersebut dapat dilihat dari profitabilitas signifikansi sebesar 0,015 dibawah 0,05. Variabel return on equity berpengaruh positif signifikan terhadap terhadap harga saham. Hal tersebut dapat dilihat dari profitabilitas signifikansi sebesar 0,013 dibawah 0,05.

\section{Uji Kelayakan Model}

Uji F digunakan untuk mengetahui apakah permodelan yang dibangun memenuhi kriteria fit atau tidak layak/fit. Model regresi dikatakan layak apabila nilai $\mathrm{F}$ hit $>\mathrm{F}$ tab atau nilai Sig <5\%, (Ferdinand,2013).

Untuk menganalisi besarnya pengaruh current ratio,debt to equity ratio, return on asset, dan return on equity terhadap harga saham, maka dilakukan uji $\mathrm{F}$ dan uji Determinasi (R2). Uji F dilakukan untuk menguji apakah secara simultan variabel current ratio (X1), debt to equity ratio (X2), return on asset (X3), dan return on equity (X4), berpengaruh terhadap harga saham. Jika nilai $\mathrm{F}<$ tingkat signifikansi $(\alpha)$ atau $\mathrm{F}$ hit > F tab maka Ha diterima dan Ho ditolak. Analisis data yang telah dilakukan dengan bantuan program SPSS 21 yang tampak pada tabel 4.6 diperoleh F $=4.907$ dengan $p=0,003$. Pada tingkat siknifikansi $\alpha=5 \%$; maka $F$ hit tersebut signifikan (tidak dapat diabaikan ). Karena $\mathrm{p}=0,003<0,05$. 
Berdasarkan hasil pengujian hipotesis tersebut maka dapat disimpulkan bahwa current ratio, debt to equity ratio, return on asset dan return on requity bersama-sama (simultan) berpengaruh terhadap harga saham.

\section{Pengujian Signifikan Parameter Individual (uji t)}

\begin{tabular}{|c|c|c|c|c|c|}
\hline \multirow{3}{*}{ Model } & \multicolumn{5}{|c|}{ Coefficients $^{a}$} \\
\hline & \multicolumn{2}{|c|}{$\begin{array}{l}\text { Unstandardized } \\
\text { Coefficients }\end{array}$} & \multirow{2}{*}{$\begin{array}{c}\text { Standardized } \\
\text { Coefficients } \\
\text { Beta }\end{array}$} & \multirow[t]{2}{*}{$\mathrm{T}$} & \multirow[t]{2}{*}{ Sig. } \\
\hline & $B$ & Std. Error & & & \\
\hline \multirow{5}{*}{\begin{tabular}{|l} 
(Constant) \\
CR \\
1 DER \\
ROA \\
ROE
\end{tabular}} & 1010.639 & 378.104 & & 2.673 & .011 \\
\hline & 50.127 & 80.958 & .097 & .619 & .540 \\
\hline & 145.355 & 171.739 & .230 & .846 & .403 \\
\hline & 173.568 & 67.665 & 1.055 & 2.565 & .015 \\
\hline & -101.056 & 38.399 & -1.038 & -2.632 & .013 \\
\hline
\end{tabular}

a. Dependent Variable: HARGA SAHAM

Hasil olahan data SPSS pada tabel 4.9 memperlihatkan tabel yang dilihat pada tabel $t$ $\alpha=0,05$ dengan $\operatorname{Df}(n-k-1)=34$ maka nilai tabel diperoleh sebesar 1.69092. Jika thitung $<$ tabel maka dapat disimpulkan bahwa $\mathrm{H} 0$ diterima sebaliknya jika thitung $>$ tabel maka $\mathrm{H} 0$ ditolak, dengan kata lain terdapat pengaruh variabel independen dengan dependen yakni harga saham.

\section{Hasil pengujian hipotesis 1}

Hipotesis ini bertujuan untuk menguji current ratio terhadap harga saham. Hasil pengujian menunjukan bahwa thitung=0,619 dan nilai sig atau probabilitas sebesar $=0,540$. Dengan memperhatikan syarat : thitung $(0,619)<$ ttabel $(1.69092)$ dan nilai sig atau profitabilitas $(0,540)>\alpha(0,05)$. Maka hasil untuk pengujian hipotesis pertama adalah H0 diterima dan H1 ditolak. Dengan demikian, current ratio tidak berpengaruh positif signifikan terhadap harga saham.

\section{Hasil pengujian hipotesis 2}

Hipotesis ini bertujuan untuk menguji debt to equity ratio terhadap harga saham. Hasil pengujian menunjukan bahwa thitung $=0,846$ dan nilai sig atau probabilitas sebesar $=0$, 403. Dengan memperhatikan syarat : thitung $(0,846)<$ ttabel $(1.69092)$ dan nilai sig atau profitabilitas $(0,403)>\alpha(0,05)$. Maka hasil untuk pengujian hipotesis pertama adalah $\mathrm{H} 0$ diterima dan $\mathrm{H} 1$ ditolak. Dengan demikian, debt to equity ratio tidak berpengaruh positif signifikan terhadap harga saham.

\section{Hasil pengujian hipotesis 3}


Hipotesis ini bertujuan untuk menguji return on asset terhadap harga saham. Hasil pengujian menunjukan bahwa thitung $=2,565$ dan nilai sig atau probabilitas sebesar $=0,015$. Dengan memperhatikan syarat $: \mathrm{t}$ hitung $(2,565)>\mathrm{t}$ tabel $(1.69092)$ dan nilai sig atau profitabilitas $(0,015)>\alpha(0,05)$. Maka hasil untuk pengujian hipotesis pertama adalah H0 ditolak dan H1 diterima. Dengan demikian, return on asset berpengaruh positif signifikan terhadap harga saham.

\section{Hasil pengujian hipotesis 4}

Hipotesis ini bertujuan untuk menguji return on equity terhadap harga saham. Hasil pengujian menunjukan bahwa thitung=-2,632 dan nilai sig atau probabilitas sebesar $=0,013$. Dengan memperhatikan syarat : thitung $(2,632)>$ ttabel (1.69092) dan nilai sig atau profitabilitas $(0,013)>\alpha(0,05)$. Maka hasil untuk pengujian hipotesis pertama adalah $\mathrm{H} 0$ ditolak dan $\mathrm{H} 1$ diterima. Dengan demikian, return on asset berpengaruh positif dan signifikan terhadap harga saham.

\section{Koefisien Determinasi (R2)}

Pengujian ini dilakukan untuk mengetahui tingkat presentase kemampuan variabel independen dalam menerangkan variabel dapendennya. Nilai dari koefisien determinasi ini dapat dilihat Adjusted $R$ Square. Berdasarkan data yang diolah menggunakan SPSS diperoleh hasil sebagai berikut :

\begin{tabular}{|l|r|r|r|r|r|}
\hline Model & $\mathrm{R}$ & $\mathrm{R}$ Square & $\begin{array}{c}\text { Adjusted R } \\
\text { Square }\end{array}$ & $\begin{array}{c}\text { Std. Error of the } \\
\text { Estimate }\end{array}$ & Durbin-Watson \\
\hline 1 & $.605^{\mathrm{a}}$ & .366 & .291 & 581.16048 & 1.371 \\
\hline
\end{tabular}

a. Predictors: (Constant), ROE, DER, CR, ROA

b. Dependent Variable: HARGA SAHAM

Berdasarkan tabel 4.10 diperoleh nilai koefisien determinasi (Adjusted R Square) sebesar 0,291, hal ini berarti current ratio,debt to equity ratio, return on asset dan return on equity mempunyai $29,1 \%$ secara bersama-sama untuk dapat menjelaskan atau menerangkan variabel harga saham. Sedangkan sisanya $(100-29,1 \%=70,9 \%)$ dijelaskan variabel lain yang mempengaruhi harga saham.

\section{PEMBAHASAN}

Berdasar hasil penelitian beserta pengolahannya yang bersumber dari laporan keuangan yang terdaftar di Bursa Efek Indonesia (BEI) dan Annual Report pada tahun 
2010-2014, maka akan diuraikan hasil penelitian sesuai dengan permasalahan yang diajukan. Dalam pengujian secara persial variabel current ratio dan debt to equity ratio tidakberpengaruh signifikan terhadap harga saham. Sedangkan return on asset dan return on equity berpengaruh positif dan signifikan terhadap harga saham. Pembahasan masing-masing dalam pengujian secara persial adalah sebagai berikut:

\section{Pengaruh Current Ratio Terhadap Harga Saham}

Hasil pengujian untuk variabel current ratio menunjukan bahwa current ratio tidak berpengaruh signifikan terhadap harga saham. Nilai CR yang tinggi belum tentu baik ditinjau dari segi profitabilitasnya. Sawir (2005:9) menyatakan bahwa CR yang rendah akan berakibat pada menurunnya harga pasar saham perusahaan bersangkutan, namun CR terlalu tinggi belum tentu baik karena pada kondisi tertentu hal tersebut menunjukkan banyak dana perusahaan yang menganggur (aktivitas sedikit) yang pada akhirnya dapat mengurangi kemampuan laba perusahaan. Senada dengan Sawir, Prastowo (1995) mengungkapkan CR yang tinggi dapat disebabkan adanya piutang yang tidak tertagih dan persediaan yang belum terjual, yang tentunya tidak dapat digunakan secara cepat untuk membayar utang lancarnya.Dari argumentasi di atas, disimpulkan CR berpengaruh negatif terhadap hargasaham.Hal ini didukung oleh bukti empiris yang dilakukan oleh Sulaiman dan Handi (2008) serta Hernendiastoro (2005) yang menunjukkan CR berpengaruh negatif terhadap harga saham.

Tingkat current ratio yang tinggi cenderung mendorong perusahaan untuk meningkatkan laporan keuangan pada perusahaan LQ45. Salah satunya dengan perbaikan tata kelola perusahaan atau harga saham. Oleh karena itu, dapat disimpulkan bahwa semakin tinggi tingkat current ratio perusahaan akan mendorong peningkatan kualitas harga saham. Sebaliknya, semakin rendah tingkat current ratio perusahaan akan cenderung menurunkan kualitas harga saham.

\section{Pengaruh Current Ratio Terhadap Harga Saham}

Hasil pengujian untuk variabel current ratio menunjukan bahwa current ratio tidak berpengaruh signifikan terhadap harga saham. Nilai CR yang tinggi belum tentu baik ditinjau dari segi profitabilitasnya. Sawir (2005:9) menyatakan bahwa CR yang rendah akan berakibat pada menurunnya harga pasar saham perusahaan bersangkutan, namun CR terlalu tinggi belum tentu baik karena pada kondisi tertentu hal tersebut menunjukkan banyak dana perusahaan yang menganggur (aktivitas sedikit) yang pada 
akhirnya dapat mengurangi kemampuan laba perusahaan. Senada dengan Sawir, Prastowo (1995) mengungkapkan CR yang tinggi dapat disebabkan adanya piutang yang tidak tertagih dan persediaan yang belum terjual, yang tentunya tidak dapat digunakan secara cepat untuk membayar utang lancarnya.Dari argumentasi di atas, disimpulkan CR berpengaruh negatif terhadap hargasaham.Hal ini didukung oleh bukti empiris yang dilakukan oleh Sulaiman dan Handi (2008) serta Hernendiastoro (2005) yang menunjukkan CR berpengaruh negatif terhadap harga saham.

Tingkat current ratio yang tinggi cenderung mendorong perusahaan untuk meningkatkan laporan keuangan pada perusahaan LQ45. Salah satunya dengan perbaikan tata kelola perusahaan atau harga saham. Oleh karena itu, dapat disimpulkan bahwa semakin tinggi tingkat current ratio perusahaan akan mendorong peningkatan kualitas harga saham. Sebaliknya, semakin rendah tingkat current ratio perusahaan akan cenderung menurunkan kualitas harga saham.

\section{Pengaruh Return On Asset Terhadap Harga Saham}

Berdasar hipotesis tersebut, menunjukan bahwa return on asset(ROA) berpengaruh positif secara signifikan terhadap harga saham. Return On Asset (ROA) yaitu rasio yang menggambarkan kemampuan perusahaan untuk menghasilkan keuntungan dari setiap satu rupiah asset menilai apakah perusahaan ini efisien dalam memanfaatkan aktivanya dalam kegiatan operasional perusahaan. Saat laba sebelum bunga dan pajak naik dan total aktiva turun maka ROA akan naik, semakin besar ROA semakin besar tingkat keuntungan yang dicapai perusahaan. Ini menunjukkan bahwa manajemen dapat menggunakan total aktiva perusahaan dengan baik (aktiva lancar dan aktiva tetap) dan pada akhirnya akan meningkatkan harga saham perusahaan sehingga menarik banyak investor untuk menanamkan modalnya di perusahaan. Rasio ini juga memberikan ukuran yang lebih baik atas profitabilitas perusahaan karena menunjukkan efektifitas manajemen dalam menggunakan aktiva untuk memperoleh pendapatan. Hasil penelitian ini sejalan dengan penelitian yang dilakukan oleh Darsono \& Ashari (2005).

\section{Pengaruh Return On Equity Terhadap Harga Saham}

Berdasarkan hasil pengujian hipotesis, menunjukan bahwa variabel return on equity berpengaruh positif signifikan terhadap harga saham. Return on equity (ROE) merupakan rasio keuangan yang banyak digunakan untuk mengukur kinerja 
perusahaan, khususnya menyangkut profitabilitas perusahaan. Return on equity (ROE) untuk mengukur kemampuan perusahaan untuk menghasilkan laba atas modalnya sendiri. Menurut Harahap (2001) dalam Rinati (2008) ROE digunakan untuk mengukur besarnya pengembalian terhadap investasi para pemegang saham. Angka tersebut menunjukkan seberapa baik manajemen memanfaatkan investasi para pemegang saham. ROE diukur dalam satuan persen. Tingkat ROE memiliki hubungan yang positif dengan harga saham, sehingga semakin besar ROE semakin besar pula harga pasar, karena besarnya ROE memberikan indikasi bahwa pengembalian yang akan diterima investor akan tinggi sehingga investor akan tertarik untuk membeli saham tersebut, dan hal itu menyebabkan harga pasar saham cenderung naik.

\section{KESIMPULAN}

Dari hasil analisis data, pengujian hipotesis dan pembahasan, maka dapat ditarik kesimpulan dari penelitian ini sebagai berikut :

1. Variabel current ratio (CR) berpengaruh positif secara signifikan terhadap harga saham. Semakin tinggi tingkat current ratio perusahaan, maka semakin baik harga saham.

2. Variabel Debt To Equity Ratio (DER) berpengaruh positif secara signifikan terhadap harga saham. Hasil penelitian ini sejalan dengan penelitian yang dilakukan oleh Dharmastuti (2004) dalam Patriawan (2004) yang menyatakan bahwa DER berpengaruh positif terhadap harga saham.

3. Variabel Return On Asset berpengaruh positif secara signifikan terhadap harga saham. Hasil penelitian ini sejalan dengan peneilitan yang dilakukan oleh oleh Darsono \& Ashari (2005) yang menyatakan bahwa ROA berpengaruh positif terhadap harga saham.

4. Variabel Return On Equity tidak berpengaruh secara signifikan terhadap harga saham. Hasil penelitian ini sejalan dengan penelitian yang dilakukan oleh Dharmastuti (2004) dalam Patriawan (2011) yang menyatakan bahwa ROE tidak berpengaruh secara signifikan terhadap harga saham.

\section{Saran}

Saran yang dapat penulis berikan adalah sebagai berikut :

1. Bagi perusahaan : 
a. Perusahaan harus lebih meningkatkan Return On Equity sehingga dapat meningkatkan harga saham.

b. Penambahan kualitas perusahaan sebagai upaya peningkatan harga saham.

2. Bagi pemerintah :

Pemerintah yang terkait harus lebih memperhatikan kembali regulasi yang terdapat di BEI supaya dapat meningkat laporan keuangan perusahaan LQ45 yang sudah tidak listing kembali.

3. Bagi penelitian :

Peneliti selanjutnya dapat menambah variabel, serta memperluas kembali kasus dan tahun penelitian.serta memperluaskan sampel perusahaan sehingga data yang diperoleh semaakin banyak dengan variasi data yang besar. 


\section{DAFTAR PUSTAKA}

Aang, R. (1997). Buku Pintar Pasar Modal Indonesia (pertama ed.). Jakarta: Mediasoft Indonesia.

Amaliah Itabillah, 2012. Pengaruh Current Ratio (CR), Quick Ratio (QR), Net Profit Margin (NPM), Return On Asset (ROA), Earning Per Share (EPS), Return On Equity (ROE), Debt to Equity Ratio (DER) Dan Price Book Value (PBV) Terhadap Harga Saham Perusahaan Property Dan Real Estate Yang Terdaftar Di BEI. Jurnal Akuntansi dan Keuangan, Vol. 3 No.1 http://jurnal.umrah.ac.id/wp-content/uploads/2013/08 diakses 21 April 2015

Anoraga.P, dan Pakarrti. P. (2003). Pengantar Pasar Modal. Jakarta: Rineka cipta.

Darmadji, Tjiptono dan Hendy M.Fakhrudin. (2006). Pasar Modal di Indonesia Pendekatan Tanya Jawab. Jakarta: Salemba Empat

Darmadji, dan Fakshruddin. (2009). Pasar Modal Indonesia (3 ed.). Jakarta: Salemba Empat.

Darsono, Ashari. 2005. Pedoman Praktis memahami laporan keuangan. Andi:Yogyakarta

Ewijaya, 1999. Analisi Pengaruh Pemecahan Saham Terhadap Perubahan Harga Saham. Penerbit: Jurnal Riset Akuntansi Indonesia. Vol 2, No 1, http://ejournal.uajy.ac.id/3491/6/5EA15585 diakses 30 Juli 2015

Fred, Weston, J. dan Thomas E. Copeland. 1999. Manajemen Keuangan. Edisi 8. Jakarta: Bina Rupa Aksara.

Ghozali, I. (2005). Aplikasi Analisis Multivariate dengan Program SPSS. Semarang: Universitas Diponegoro.

Hanafi, Mamduh M. 2008. Manajemen Keuangan. Edisi 1. Yogyakarta: BPFE.

Harahap, Sofyan Syafri. 2007. Analisis Kritis Atas Laporan Keuangan. Jakarta: PT Raja Grasindo Persada.

Husnan, Suad dan Enny Pudjiastuti. 1998. Dasar-Dasar Teori Portofolio dan Analisis Sekuritas. Edisi 2. Yogyakarta: UPP AMP YKPN

Husnan S. Dan Pujiastuti, 2006. Dasar-Dasar Manajemen Keuangan, Edisi Ke lima UPP STIM YKPN, Yogyakarta.

Martalena dan Melinda (2011). Dalam puspita sari (2011). Pengantar pesan modal. Edisi 1. Andi Yogyakarta.

Jogiyanto. 2003. Analisis Sekuritas dan Analisis Portofolio. Yogyakarta :PT. BPFE.

.Kasmir, 2010.Pengantar Manajemen Keuangan. Edisi pertama.Catatan ke-2. Kencana, Jakarta

M. Fuad, dkk. 2006. Pengantar Bisnis. Jakarta: Erlangga

Nurmalasari, Indah. (2008). Analisis Pengaruh Rasio Profitabilitas Terhadap Harga Saham Emitem LQ45 Yang Terdaftar Di Bursa Efek Indonesia Tahun 20052008. Jurnal Ekonomi dan Manajemen. Universitas Gunadarma. 
Pakarti dan Anoraga (2001) dalam Rinati, Ina. (2008). Pengaruh Net Profit Margin (NPM), Return On Assets (ROA) danReturn On Equity (ROE) terhadap Harga Saham pad Perusahaan yangTercantum Indeks LQ45. Jurnal Ekonomi dan Manajemen. Universitas Gunadarma.

Patriawan, Dwiatma, 2009 . Analisis Pengaruh Earning Per Share (EPS), Return On Equity (ROE), Dan Debt To Equity Ratio (DER) Terhadap Harga Saham Pada Perusahaan Wholesale and Retail Trade Yang Terdaftar di Bursa Efek Indonesia (BEI) Tahun 2006 - 2008. Eprint.undip.ac.id/28968 diakses 21 april 2015.

Ross, Stephen A and et al. 2008. Modern Financial Management. Eight Edition, McGraw-Hill Irwin

Sunariyah. 2004. Pengantar Pengetahuan Pasar Modal. Yogyakarta: UPP AMP YKPN.

Sugiyono, 2007.Metode Penelitian dan Bisnis (Pendekatan Kuantitatif, Kualitatif ). Penerbit: Alfabeta, Bandung.

Sekaran, Uma 2006. Metodologi Penelitian untuk Bisnis, Edisi 4, Buku 1,Jakarta: Salemba Empat.

.Sugiyono. (2008). Metode Penelitian Kuantitatif, Kualitatif dan R\&D. Yogyakarta: CV.Alfabeta.

Suad Husnan,. 2001. Dasar-Dasar Teori Portofolio Dan Analisis Sekuritas. Yogyakarta : AMP YPKN.

Sjahrial, Dermawan. (2009). Pengantar Manajemen Keuangan. Edisi Ketiga. Jakarta : Mitra Wacana Media.

Suhartono dan Qudsi Fadlillah. (2009). Portofolio Investasi dan Bursa Efek Pendekatan Teori dan Praktek. Edisi ke-1. Yogyakarta : YKPN.

Sugiyono. 2013. Metode Peneitian Bisnis. Alfa Beta; Bandung

Tandelilin, Eduardus. 2001. Portofolio dan Investasi Teori dan Aplikasi. Yogyakarta: Kanisius

Tandelilin, Eduardus, 2010, Portofolio dan Investasi teori dan aplikasi, Edisi Pertama. KANISIUS; Yogyakarta

Tandelilin, E. (2010). Portofolio dan Investasi teori dan aplikasi, . Yogyakarta: Kanisius. 